\title{
SISTEM PAKAR MENGIDENTIFIKASI PENYAKIT ALAT REPRODUKSI MANUSIA MENGGUNAKAN METODE FORWARD CHAINING
}

\author{
Marwan Hakim ${ }^{1)}$ \\ ${ }^{1)}$ STMIK Syaikh Zainuddin NW \\ Jln. Raya Mataram - Lb Lombok KM 49 Desa Anjani Lombok Timur \\ e-mail: ten2one7@yahoo.co.id ${ }^{1)}$
}

\begin{abstract}
ABSTRAK
Kesehatan reproduksi adalah suatu keadaan sehat mental, fisik dan kesejahteraan sosial secara utuh pada semua yang berhubungan dengan sistem dan fungsi serta proses dan bukan hanya kondisi yang bebas dari penyakit dan kecacatan serta dibentuk berdasarkan atas perkawinan yang sah, mampu memenuhi kebutuhan spiritual dan material yang layak, bertakwa pada Tuhan Yang Maha Esa, spiritual memiliki hubungan yang serasi, selaras, seimbang antara anggota keluarga dan antara keluarga dan masyarakat dan lingkungan. Kesehatan reproduksi mencakup tiga komponen yaitu: kemampuan (ability), keberhasilan (success), dan keamanan (safety). Sistem pakar merupakan jawaban yang tepat untuk permasalahan di atas karena sistem pakar adalah suatu sistem yang dirancang untuk dapat menirukan keahlian seorang pakar atau ahli dalam menjawab pertanyaan dan memecahkan suatu masalah. Pemecahan masalah diberikan pada pemakai melalui dialog dengan mereka sehingga membantu seseorang yang bukan pakar/ahli dalam menjawab pertanyaan, menyelesaikan masalah dan mengambil keputusan yang biasanya dilakukan oleh seorang pakar. Metode yang digunakan dalam representasi pengetahuan adalah forward chaining. tersebut memberikan hasil berupa kemungkinan penyakit kelamin yang dialami oleh pengguna, diagnosa pada sistem ini dilakukan dengan cara pengguna mengisi keluhan atau gejala yang dialami ketika menggunakan system ini. Hasil perancangan akan dibuat dengan menggunakan Bahasa Pemrograman Delphi 7, karena dapat membuat program aplikasi yang sesuai dengan tampilan yang user friendly.
\end{abstract}

Kata Kunci : Forward Chaining Inference, Alat reproduksi manusia

\begin{abstract}
Reproductive health is a state of mental health, physical and social welfare as a whole in all related to the systems and functions and processes and not just conditions that are free from disease and disability and are formed based on legal marriage, able to meet the proper spiritual and material needs, devoted to God Almighty, spiritual have a harmonious, harmonious, balanced relationship between family members and between family and society and the environment. Reproductive health includes three components, namely: ability, success, and safety. Expert system is the right answer to the above problems because the expert system is a system designed to be able to imitate the expertise of an expert or expert in answering questions and solving a problem. Problem solving is given to users through dialogue with them so that helps someone who is not an expert in answering questions, solving problems and making decisions that are usually done by an expert. The method used in knowledge representation is forward chaining. The results provide the possibility of venereal disease experienced by the user, the diagnosis in this system is done by the user filling out complaints or symptoms experienced when using this system. The results of the design will be made using the Delphi 7 Programming Language, because it can create application programs that match the user friendly appearance.
\end{abstract}

Keywords: Forward Chaining Inference, Human reproduction tools

\section{Pendahuluan}

$\mathrm{P}$ erkembangan teknologi saat ini membawa pengaruh luar biasa bagi gaya hidup setiap orang. Dengan terus berkembangnya pola pikir dan peradaban manusia, muncul konsep atau ide bahwa komputer tidak hanya digunakan sebatas di atas meja saja, tetapi harus dapat digunakan untuk berpindah-pindah tempat (mobile). Teknologi zaman sekarang sudah banyak diterapkan diberbagai bidang seperti dalam bidang perdagangan, perbankan, pendidikan dan kedokteran.

Kesehatan adalah keadaan sejahtera badan, jiwa, dan sosial yang memungkinkan setiap orang hidup produktif secara sosial dan ekonomi. ${ }^{[1]}$ Kesehatan reproduksi adalah suatu keadaan sehat mental, fisik dan kesejahteraan sosial secara utuh pada semua yang berhubungan dengan sistem dan fungsi serta proses dan bukan hanya kondisi yang bebas dari penyakit dan kecacatan serta 
dibentuk berdasarkan atas perkawinan yang sah, mampu memenuhi kebutuhan spiritual dan material yang layak, bertakwa pada Tuhan Yang Maha Esa, spiritual memiliki hubungan yang serasi, selaras, seimbang antara anggota keluarga dan antara keluarga dan masyarakat dan lingkungan (BKKBN, 1996). Kesehatan reproduksi mencakup tiga komponen yaitu: kemampuan (ability), keberhasilan (success), dan keamanan (safety). Kemampuan berarti dapat berproduksi. Keberhasilan berarti dapat menghasilkan anak sehat yang tumbuh dan berkembang. Keamanan berarti semua proses reproduksi termasuk hubungan seks, kehamilan, persalinan, kontrasepi, dan abortus seyogyanya bukan aktifitas yang berbahaya. Menurut Ida Bagus Gde Manuaba, 1998 kesehatan reproduksi adalah kemampuan seseorang untuk dapat memamfaatkan alat refroduksi dengan mengukur kesuburannya dapat menjalani kehamilannya dan persalinan serta aman mendapatkan bayi tanpa resiko apapun (Well Health Mother Baby) dan selanjutnya mengembalikan kesehatan dalam batas normal. Seiring maraknya perkambangan generasi sekarang yang sudah mengenal pergaulan bebas, tidak dipungkiri para generasi sekarang bisa terjangkit penyakit menular seksual.

Sistem Pakar (Expert System) adalah program berbasis pengetahuan yang menyediakan solusi-solusi dengan kualitas pakar untuk problema-problema dalam suatu domain yang spesifik. Sistem pakar merupakan program komputer yang meniru proses pemikiran dan pengetahuan pakar dalam menyelesaikan suatu masalah tertentu. Implementasi sistem pakar banyak digunakan dalam bidang psikologi karena sistem pakar dipandang sebagai cara penyimpanan pengetahuan pakar pada bidang tertentu dalam program komputer sehingga keputusan dapat diberikan dalam melakukan penalaran secara cerdas.[2]

Untuk itu peranan teknologi informasi khususnya bidang kecerdasan buatan sub bidang sistem pakar dapat memberikan sebuah solusi yang baik pada dunia kedokteran. Oleh karena itu penerapan ini dirasa perlu mengingat akan tingkat pemahaman para generasi kepada kesehatan alat reproduksi. Dari itu ilmu teknologi komputer dapat dimanfaatkan sebagai alternatif baru untuk memberikan informasi bagi generasi sekarang yang mengalami penyakit menular seksual (PMS).

Dengan permasalahan di atas maka peneliti memberikan solusi dengan membuat sistem pakar menggunakan metode Forward Chaining yang bisa digunakan oleh para penderita atau generasi sekarang untuk mengkonsultasikan gejala-gejala yang dialami. Program aplikasi ini akan memberikan kesimpulan dari gejala-gejala yang dialami penggguna atau penderita dengan tepat.

\section{STUDI PUSTAKA}

\section{A. Kecerdasan Buatan secara umum}

Kecerdasan Buatan adalah salah satu bidang ilmu komputer yang mendaya gunakan komputer sehingga dapat berprilaku cerdas seperti manusia. Aktivitas manusia yang ditirukan seperti penalaran, penglihatan, pembelajaran, pemecahan masalah pemahaman bahasa alami dan sebagainya. Sesuai dengan definisi tersebut, maka teknologi kecerdasan buatan dipelajari dalam bidang-bidang seperti Robotika (Robotics), Penglihatan Komputer (Computer Vision), Pengolahan bahasa alami (Natural Language Processing), Pengenalan pola (Pattern Recognition), sistem syaraf Buatan (Artificial Neural System), Pengenalan Suara (Speech Recognition), dan System Pakar (Expert System). [3]

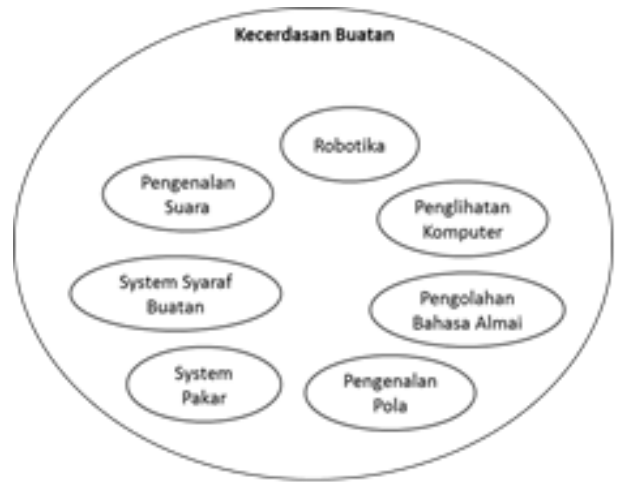

Gambar 1. Beberapa Bidang kecerdasan Buatan

Pemecahan masalah-masalah yang komplek biasanya hanya dapat dilakukan oleh sejumlah orang yang sangat terlatih yaitu pakar, dengan teknis penerapan kecerdasan buatan, sistem pakar menirukan apa yang dikerjakan oleh pakar ketika mengatasi permasalahan yang rumit, berdasarkan pengetahuan yang dimilikinya.

\section{B. Sistem Pakar}

Beberapa definisi sistem pakar menurut para ahli [3] disajikan dalam tabel 1 sebagai berikut :

Tabel 1. Definisi Sistem Pakar

\begin{tabular}{|c|l|}
\hline Sumber & \multicolumn{1}{|c|}{ Definisi } \\
\hline $\begin{array}{c}\text { Martin dan } \\
\text { Oxman } \\
(1988)\end{array}$ & $\begin{array}{l}\text { Sistem berbasis komputer menggunakan } \\
\text { pengetahuan, fakta, dan teknik penalaran } \\
\text { dalam memecahkan masalah, yang bi- } \\
\text { asanya hanya dapat diselesaikan oleh } \\
\text { seorang pakar dalam bidang tetentu. }\end{array}$ \\
\hline & $\begin{array}{l}\text { Sistem pakar merupakan bidang yang dici- } \\
\text { rikan oleh sistem berbasis pengetahuan } \\
\text { (Knowledge Base System), memungkinkan } \\
\text { komputer dapat berfikir dan mengambil } \\
\text { kesimpulan dari sekumpulan kaidah. }\end{array}$ \\
\hline $\begin{array}{c}\text { Tynizo } \\
\text { Aronson dan } \\
\text { (2001) }\end{array}$ & $\begin{array}{l}\text { Sistem yang menggunakan pengetahuan } \\
\text { manusia yang dimasukkan kedalam kom- } \\
\text { puter untuk memecahkan masalah-masalah } \\
\text { yang biasanya diselesaikan oleh pakar. }\end{array}$ \\
\hline
\end{tabular}


Galah satu cabang kecerdasan buatan yang menggunakan pengetahun-pengetahuan dan Riley khusus yang dimiliki oleh seorang ahli un(2005) tuk menyelesaikan suatu masalah tertentu

\section{1) Komponen Sistem Pakar}

Sistem Pakar sebagai sebuah program yang difungsikan untuk menirukan pakar manusia harus bisa melakukan hal-hal yang dapat dikerjakan oleh seorang pakar. Untuk membangun sistem yang seperti itu maka komponen-komponen yang harus dimiliki adalah sebagai berikut : [3]

a) Antar Muka Pengguna (User Interface).

Sistem pakar menggantikan seorang pakar dalam suatu situasi tertentu, maka sistem harus menyediakan pendukung yang diperlukan oleh pemakai yang tidak memahami masalah teknis. Sistem pakar juga menyediakan komunikasi antara sistem dan pemakainya, yang disebut dengan Antar Muka.

b) Basis Pengetahuan (Knowledge).

Basis Pengetahuan merupakan kumpulan pengetahuan bidang tertentu pada tingkatan pakar dalam format tertentu. Pengetahuan ini diproleh dari akumulasi pengetahuan pakar dan sumbersumber pengetahuan lainnya seperti yang telah disebutkan sebelumnya. Basis pengetahuan bersifat dinamis bisa berkembang dari waktu ke waktu.

c) Mekanisme Inferensi (Inference Machine).

Mesin Inferensi adalah otak dari sistem pakar, berupa perangkat lunak yang melakukan tugas inferensi penalaran sistem pakar, biasa dikatakan sebagai mesin pemikir (Thinking Machine).

d) Memori Kerja (Working Memory).

Merupakan bagian dari sistem pakar yang menyimpan fakta-fakta yang diperoleh saat di akukan proses konsultasi. Fakta-fakta inilah yang nantinya akan diolah oleh mesin inferensi berdasarkan pengetahuan untuk menentukan suatu keputusan pemecahan masalah. Konklusinya bisa berupa diagnosa, tindakan, dan akibat.

\section{2) Keuntungan Sistem Pakar}

Sistem pakar (Expert System), merupakan paket perangkat lunak atau paket program komputer yang ditujukan sebagai penyedia nasihat dan sarana bantu dalam memecahkan masalah dibidang-bidang spesialisasi tertentu seperti sains, perekayasaan, matematika, kedokteran, pendidikan dan sebagainya. Sistem pakar merupakan subset dari Artificial Intelegence.

Ada beberapa keunggulan Sistem Pakar (Expert System), diantaranya adalah sebagai berikut.

a) Menghimpun data dalam jumlah yang sangat besar

b) Menyimpan data tesebut untuk jangka waktu yang panjang dalam suatu bentuk tertentu c) Mengerjakan perhitungan secara cepat dan tepat dan tanpa jemu mencari kembali data yang tersimpan dengan kecepatan tinggi.

\section{3) Kemampuan Sistem Pakar}

a) Menjawab berbagai pertanyaan yang menyangkut bidang keahliannya

b) Bila diperlukan dapat menyajikan asumsi dan alur penalaran yang diinginkan untuk sampai ke jawaban yang dikehendaki.

c) Menambah fakta kaidah dan alur penalaran sahih yang baru ke dalam otaknya.

4) Keuntungan Menggunakan Sistem Pakar

a) Menjadikan pengetahuan dan nasihat lebih mudah didapat

b) Meningkatkan output dan produktivitas.

c) Menyimpan kemampuan dan keahlian pakar

d) Meningkatkan reliabilitas

e) Memberikan respone (Jawaban yang cepat).

f) Merupakan panduan yang cerdas (Intelegence).

g) Intelegence Database (Basis data Cerdas), bahwa sistem pakar dapat digunakan untuk mengakses basis data dengan cara cerdas (Kerscberg, 1986).

5) Beberapa Kelemahan Menggunakan Sistem Pakar

a) Masalah dalam mendapatkan pengetahuan di mana pengetahuan tidak selalu bisa didapatkan dengan mudah karena kadangkala pakar dari masalah yang kita buat tidak ada, dan kalaupun ada kadang-kadang pendekatan yang di miliki oleh pakar berbeda-beda.

b) Untuk membuat suatu sistem pakar yang benarbenar berkualitas tinggi sangatlah sulit dan memerlukan biaya yang sangat besar untuk pengembangan dan pemeliharannya.

c) Bisa jadi sistem tidak dapat membuat keputusan.

d) Sistem pakar tidaklah $100 \%$ menguntungkan, walaupun seorang tetap tidak sempurna atau tidak selalu benar. Oleh dari itu perlu diuji ulang secara teliti sebelum digunakan.

\section{6) Konsep Umum Sistem Pakar}

Pengetahuan dari suatu sistem pakar mungkin dapat dipresentasikan dalam jumlah cara. Salah satu metode yang paling umum untuk mempresentasekan pengetahuan adalah dalam bentuk tipe aturan (Rule). IF....Then (Jika....maka).

Walaupun cara di atas sangat sederhana, namun banyak hal yang berarti dalam membangun sistem pakar dengan mengekpresikan pengetahuan pakar dalam bentuk aturan di atas.

Konsep dasar dari suatu sistem pakar mengandung, beberapa unsur/elemen, yaitu, keahlian, ahli, pengalihan keahlian, inferensi, aturan, dan kemampuan menjelaskan. 
Keahlian merupakan suatu penguasaan pengetahuan dibidang tertentu yang didapatkan dari pelatihan, membaca atau pengalaman. Contoh bentuk pengetahuan yang merupakan keahlian adalah :

a) Fakta-fakta pada lingkup permasalahan tertentu

b) Teori-teori pada lingkup permasalahan tertentu

c) Prosedur-prosedur dan aturan-aturan berkenaan dengan lingkup permasalahan tertentu.

d) Strategi-strategi global untuk menyelesaikan masalah

e) Meta-Knowledge (Pengetahuan tentang pengetahuan).

\section{7) Struktur Sistem Pakar}

Sistem Pakar disusun oleh dua bagian utama, yaitu lingkungan pengembangan (Development environment), dan lingkungan konsultasi (Consultation environment).

Lingkungan pengembangan sistem pakar digunakan untuk memasukkan pengetahuan pakar dalam lingkungan sistem pakar, sedangkan lingkungan konsultasi digunakan oleh pengguna yang bukan pakar guna memperoleh pengetahuan pakar. Komponen-komponen sistem pakar dalam kedua bagian tersebut dapat dilihat dalam gambar 2 berikut :

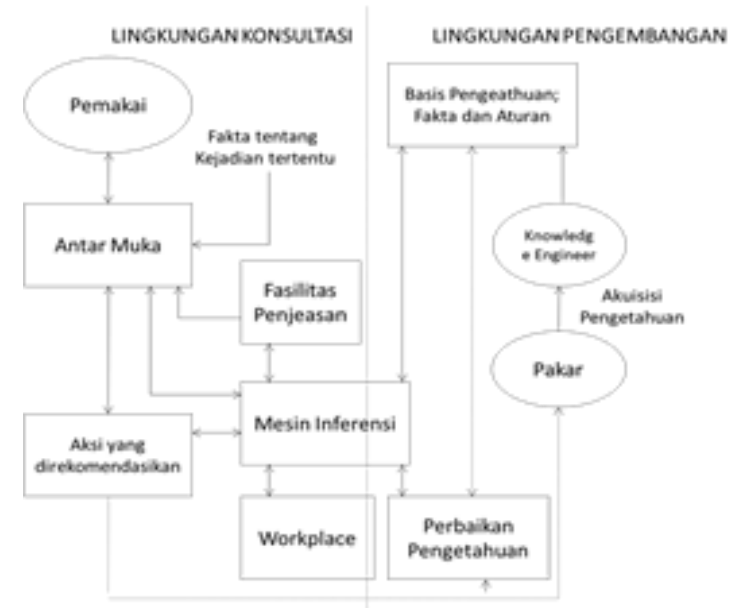

Gambar 2. Arsitektur sistem pakar

Komponen-komponen yang tedapat dalam sistem pakar adalah yang terdapat pada gambar yaitu User Interface (antarmuka pengguna), basis pengetahuan, akuisisi pengetahuan, mesin inferensi, workplace, fasilitas penjelasan, perbaikan pengetahuan.

\section{8) Mesin Inferens}

Komponen ini mengandung mekanisme pola pikir dan penalaran yang digunakan oleh pakar dalam menyelesaikan suatu masalah. Mesin inferensi adalah program komputer yang memberikan metodologi untuk penalaran tentang informasi yang ada dalam basis pengetahuan dan dalam workplace, dan untuk memformulasikan kesimpulan.

Kebanyakan sistem pakar berbasis aturan menggunakan strategi inferensi yang dinamakan modus ponen. Berdasarkan strategi ini, jika terdapat aturan "IF A THEN B", dan jika diketahui bahwa A benar, maka dapat disimpulkan bahwa B juga benar. Strategi inferensi modus ponen dinyatakan dalam bentuk.

\section{$[\mathrm{A}$ AND $(\mathrm{A} \rightarrow \mathrm{B})] \rightarrow \mathrm{B}$}

Dengan A dan A $\rightarrow B$ adalah proposisi-proposisi dalam basis pengetahuan.

Terdapat dua pendekatan untuk mengontrol inferensi dalam sistem pakar berbasis aturan, yaitu pelacakan ke belakang (backward chaining), dan pelacakan ke depan (forward chaining). Dalam pendekatan ini pelacakan dimulai dari tujuan, selanjutnya dicari aturan yang memilki tujuan tersebut untuk kesimpulannya. Selanjutnya proses pelacakan menggunakan premis untuk aturan tersebut sebagai tujuan baru dan mencari aturan lain dengan tujuan baru sebagai kesimpulannya. Proses berlanjut sampai semua kemungkinan ditemukan. Gambar 3 Menunjukkan proses backward chaining.

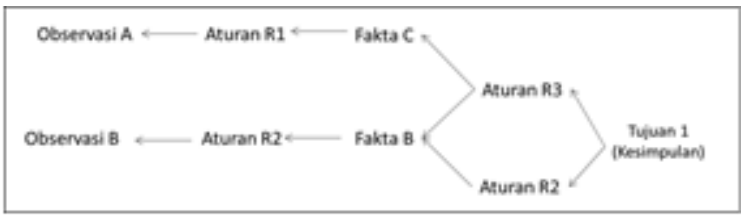

Gambar 3. Proses backward chaining

Pelacakan ke depan adalah pendekatan yang dimotori data (data-driven). Dalam pendekatan ini pelacakan dimulai dari informasi masukan, dan selanjutnya mencoba menggambarkan kesimpulan. Pelacakan ke depan mencari fakta yang sesuai dengan bagian IF-THEN. Gambar: 4. menunjukkan proses forward chaining.

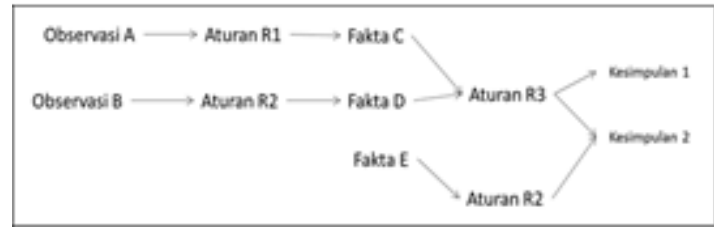

Gambar 4. Proses forward chaining

Kedua metode inferensi tersebut dipengaruhi oleh tiga macam penulusuran, yaitu Depth-first search, Breadthfirst search, dan Best-first search.

a) Depth-first search, melakukan penulusuran kaidah secara mendalam dari simpul akar bergerak menurun ke tingkat dalam yang berurutan.

b) Breadth-first search, bergerak dari simpul akar, yang ada pada setiap tingkat diuji sebelum pindah ke tingkat selanjutnya.

c) Best-first search, bekerja berdasarkan kombinasi kedua metode sebelumnya. [4]

\section{Penyakit Menular Seksual (PMS)}

Penyakit Menular Seksual (PMS) adalah suatu gangguan atau penyakit-penyakit yang di sebabkan oleh bakteri, virus, parasit, atau jamur yang di tularkan dari satu orang ke orang lain melalui kontak atau hubungan seksual. 
Penyakit kelamin adalah penyakit yang penularannya terutama melalui hubungan seksual. Cara hubungan kelamin tidak hanya terbatas secara genito-genital saja, tetapi dapat juga secara oro-genital, atau anogenital, sehuingga kelainan yang timbul akibat penyakit kelamin ini tidak terbatas hanya pada daerah genital saja, tetapi dapat juga pada daerah-daerah ekstra genital. berikut:

Jenis-jenis infeksi menular seksual adalah sebagai

a) Hepatitis

Hepatitis adalah peradangan pada hati karena toxin, seperti kimia atau obat ataupun agen penyebab infeksi.

b) Gonorrhoe

Gonorrhoe adalah penyakit menular seksual yang disebabkan oleh neisseria gonorrhoeae yang bersifat diplococcus.

c) Herpes

Herpes merupakan penyakit infeksi akut pada genital dengan gambaran khas berupa vesikel berkelompok pada dasar eritomatosa, dan cendrung bersifat rekuen.

d) Sifilis

Sifilis adalah penyakit infeksi yang disebabkan oleh Treponema pallidum, merupakan penyakit kronis dan bersifat sistemik.

e) Kondiloma Akuminata-Kutil Kelamin

Kondiloma merupakan penyakit menular seksual dan berpengaruh buruk bagi kedua pasangan.

f) Limfogranuloma Venerium

Limfogranuloma Venerium adalah suatu penyakit menular seksual yang disebabkan oleh Chlamydia trachomatis

g) HIV/AIDS

Infeksi HIV (Human Immunodeficiency Virus) adalah suatu infeksi virus yang secara progresif menghancurkan sel-sel darah putih dan menyebabka AIDS (Acquired Immunodeficiency Syndrome).

h) Ulkus Mole (Chancroid)

Disebabkan oleh bakteri hemophilus ducreyi

i) Trikomoniasis

Trikomoniasis adalah penyakit menular seksual yang disebabkan oleh parasit protozoa yang disebut Trichomonas vaginalis. [5]

\section{METODE PENELITIAN}

\section{A. Metode Inferensi}

Metode penalaran yang digunakan dalam sistem adalah penalaran pelacakan maju (Forward Chaining) yaitu dimulai dari sekumpulan fakta-fakta tentang ciriciri atau gejala-gejala penyakit yang dialami, untuk kemudian dilakukan pelacakan sampai tujuan akhir berupa diagnosis kemungkinan jenis penyakit yang dideritanya dan solusi tentang penyakit yang diderita.
Tahap ini merupakan metode pengumpulan data dan fakta yang didapat dari sumber-sumber terkait seperti buku, pendapat para pakar atau dokter, berkas internet dan penunjang lain yang terkait. Sehingga didapat sebuah kumpulan ilmu penyakit reproduksi manusia itu sendiri guna diperluas atau dikembangkan menjadi disiplin ilmu lain yaitu sistem pakar. Sistem pakar mengidentifikassi penyakit alat refroduksi manusia ini menggunakan fakta-fakta yang dibutuhkan oleh sistem dari tahap studi literatur. Sedangkan mesin inferensi digunakan untuk menganalisa fakta-fakta yang telah dipilih oleh pengguna sehingga akhirnya dapat ditentukan suatu kesimpulan.

Dalam perancangan basis pengetahuan ini digunakan kaidah produksi sebagai sarana untuk representasi pengetahuan. Kaidah produksi dituliskan dalam bentuk pernyataan JIKA [premis] MAKA [konklusi].

Bagian premis dalam aturan produksi dapat memiliki lebih dari satu proposisi yaitu berarti pada sistem pakar ini dalam satu kaidah dapat memiliki lebih dari satu gejala. Gejala-gejala tersebut dihubungkan dengan menggunakan operator logika DAN. Bentuk pernyataannya adalah:

JIKA [gejala 1]

DAN [gejala 2]

DAN [gejala 3]

MAKA [gangguan].

\section{1) Tabel keputusan}

Tabel keputusan merupakan cara untuk mendokumentasikan pengetahuan. Tabel keputusan merupakan kondisi yang menjadi pertimbangan dalam pendeskripsian kaidah.

Tabel 2. Tabel keputusan identifikasi jenis penyakit Alat Reproduksi manusia

\begin{tabular}{|c|c|c|c|}
\hline Diagnosa & JP1 & JP2 & JP3 \\
\hline G1 & Ya & ya & ya \\
\hline G2 & Ya & ya & ya \\
\hline G3 & Ya & ya & tidak \\
\hline G4 & Ya & ya & tidak \\
\hline G5 & Ya & tidak & tidak \\
\hline G6 & Tidak & ya & tidak \\
\hline G7 & Tidak & ya & tidak \\
\hline G8 & Tidak & tidak & ya \\
\hline G9 & Tidak & tidak & ya \\
\hline G10 & Tidak & tidak & ya \\
\hline
\end{tabular}

Keterangan :

\begin{tabular}{|l|l|}
\hline JP1 & Anda menderita penyakit HIV/AIDS \\
\hline JP2 & $\begin{array}{l}\text { Anda menderita penyakit SIFILIS (Raja } \\
\text { Singa) }\end{array}$ \\
\hline JP3 & $\begin{array}{l}\text { Anda menderita penyakit HERPES } \\
\text { Genitalis }\end{array}$ \\
\hline
\end{tabular}


2) Data Fakta

\begin{tabular}{|c|c|}
\hline $\begin{array}{c}\text { Jenis } \\
\text { Penyakit }\end{array}$ & Syarat/gejala \\
\hline \multirow{5}{*}{ HIV/AIDS } & - Demam \\
\hline & - $\quad$ Semua Persendian terasa nyeri \\
\hline & - Rasa lemah atau lesu \\
\hline & - $\quad$ Sakit tenggorokan \\
\hline & - $\quad$ Batuk kering \\
\hline \multirow{6}{*}{$\begin{array}{c}\text { SIFILIS } \\
\text { (Raja } \\
\text { Singa) }\end{array}$} & - Demam \\
\hline & - $\quad$ Semua Persendian terasa nyeri \\
\hline & - Rasa lemah atau lesu \\
\hline & - $\quad$ Sakit tenggorokan \\
\hline & $\begin{array}{l}\text { - Luka kecil, bundar dan tidak sa- } \\
\text { kit }\end{array}$ \\
\hline & $\begin{array}{l}\text { - Rambut rontok dan terdapat } \\
\text { bintil }\end{array}$ \\
\hline \multirow{5}{*}{$\begin{array}{c}\text { Herpes } \\
\text { Genitalis }\end{array}$} & - Demam \\
\hline & - $\quad$ Semua Persendian terasa nyeri \\
\hline & - $\quad$ Rasa sesak nafas \\
\hline & - $\quad$ Menggigil \\
\hline & $\begin{array}{l}\text { - } \text { Timbulnya bulatan-bulatan } \\
\text { kecil yang berisi cairan bening }\end{array}$ \\
\hline
\end{tabular}

\section{3) Aturan gejala}

Selain fakta-fakta tadi, basis pengetahuan juga membutuhkan aturan yang merupakan informasi tentang cara bagaimana memproses dari fakta yang telah ada. Dalam sistem pakar ini basis pengetahuan yang dibutuhkan adalah aturan jenis gejala-gejala penyakit, dan deskripsi tentang penyakit yang di derita ketika mengalami kondisi pada jenis gejala penyakit tersebut. Adapun aturan gejala yang terbentuk adalah sebagai berikut:

\begin{tabular}{|c|l|}
\hline Id & \multicolumn{1}{|c|}{ GEJALA } \\
\hline G1 & Apakah anda mengalami Demam ? \\
\hline G2 & $\begin{array}{l}\text { Apakah Persendian Anda terasa nyeri } \\
?\end{array}$ \\
\hline G3 & $\begin{array}{l}\text { Apakah tubuh anda terasa lemah atau } \\
\text { lesu ? }\end{array}$ \\
\hline G4 & $\begin{array}{l}\text { Apakah tenggorokan anda terasa sa- } \\
\text { kit } ~\end{array}$ \\
\hline G5 & $\begin{array}{l}\text { Apakah anda mengalami batuk ker- } \\
\text { ing? }\end{array}$ \\
\hline G6 & $\begin{array}{l}\text { Apakah anda mengalami luka-luka } \\
\text { kecil/bundar tapi tidak terasa sakit } ?\end{array}$ \\
\hline G7 & $\begin{array}{l}\text { Apakah rambut anda rontok dan ter- } \\
\text { dapat bintil-bintil ? }\end{array}$ \\
\hline G8 & $\begin{array}{l}\text { Apakah anda mengalami sesak nafas } \\
?\end{array}$ \\
\hline G9 & $\begin{array}{l}\text { Apakah tubuh anda terasa menggigil } \\
?\end{array}$ \\
\hline G10 & $\begin{array}{l}\text { Apakah ditubuh anda terdapat bu- } \\
\text { latan-bulatan kecil yang berisi cairan } \\
\text { bening ? }\end{array}$ \\
\hline
\end{tabular}

Tabel 4. Aturan Gejala

\begin{tabular}{|c|l|}
\hline NO & \multicolumn{1}{|c|}{ ATURAN GEJALA } \\
\hline 1 & $\begin{array}{l}\text { if Demam OR Persendian terasa } \\
\text { Nyeri OR Tubuh terasa lemah dan } \\
\text { lesu OR tenggorokan terasa sakit OR } \\
\text { mengalami batuk kering Then } \\
\text { HIV/AIDS }\end{array}$ \\
\hline 2 & $\begin{array}{l}\text { IF Demam OR Persendian terasa } \\
\text { nyeri Or tubuh terasa lemah dan lesu } \\
\text { OR tenggorokan terasa sakit OR ter- } \\
\text { dapat luka kecil atau bundar tidak sa- } \\
\text { kit OR rambut rontok dan bintil Then } \\
\text { SIFILIS }\end{array}$ \\
\hline 3 & $\begin{array}{l}\text { IF Demam OR Persendian terasa } \\
\text { nyeri OR mengalami sesak nafas OR } \\
\text { tubuh terasa menggigil OR terdapat } \\
\text { bulatan -bulatan kecil yang berisi } \\
\text { cairan bening Then Herpes }\end{array}$ \\
\hline
\end{tabular}

\section{4) Pohon Keputusan}

Berdasarkan contoh kaidah pengetahuan di atas maka kaidah tersebut dapat disimpan dalam bentuk sebuah pohon keputusan sehingga dapat lebih mudah untuk dimengerti. Dimana pada pohon keputusan tersebut terdapat ciri-ciri dan jenis gejala yang diderita, dan pada pohon keputusan yang lain terdapat pohon keputusan/kesimpulan dan saran yang menjelaskan tentang jenis penyakit yang dialami berdasarkan ciri-ciri yang telah disediakan oleh sistem dan terakhir saran. 


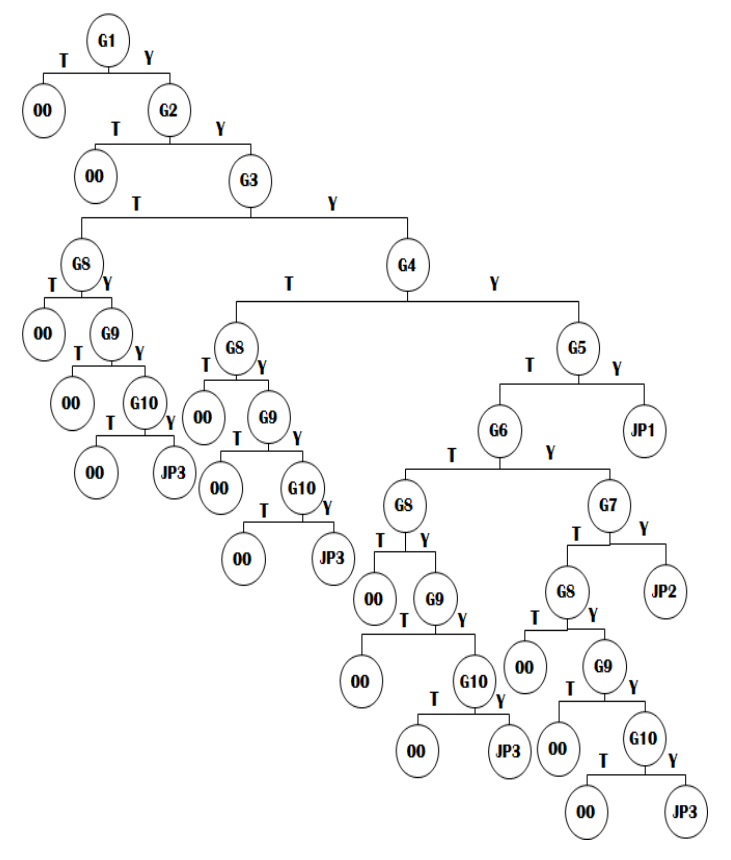

Gambar 5. Pohon keputusan forward chaining

\section{B. Unified Modeling Language (UML)}

1) Use Case

Tahap ini adalah tahap menterjemahkan prototype aplikasi sistem pakar penyakit alat reproduksi manusia dalam bentuk use case diagram untuk menjelaskan gambaran sistem dan aktor yang terlibat secara keseluruhan. Selain itu use case diagram hanya menggambarkan apa yang dilakukan oleh sistem dan tidak menggambarkan bagaimana sistem melakukannya. Komponen use case diagram terdiri dari : Actor, use case dan relation. Aktor adalah pemain, sedangkan use case adalah apa yang dimainkan/dilakukannya dengan relation sebagai penunjuknya.

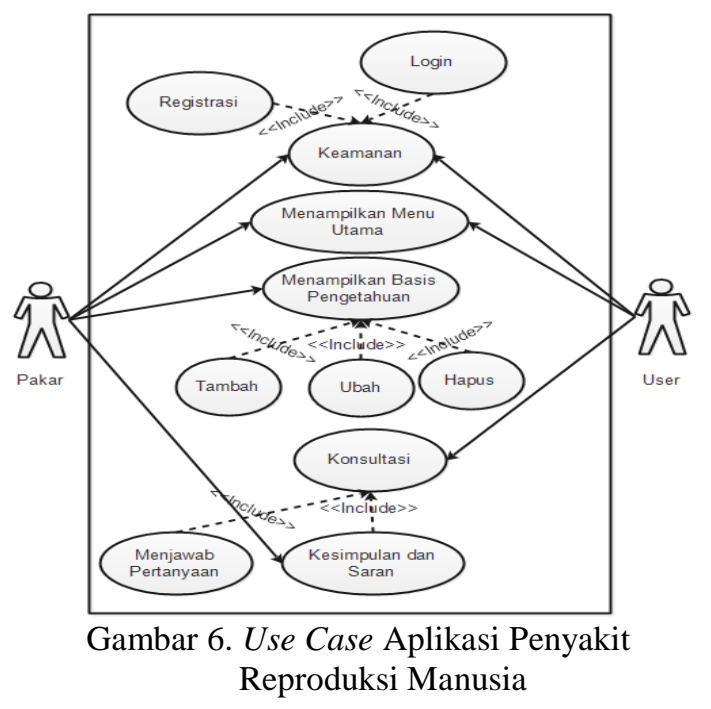

\section{2) Class Diagram}

Setelah kita membuat usecase diagram, langkah selanjutnya adalah membuat Class Diagram berdasarkan usecase diagram tersebut. Class diagram ini harus berisikan objek-objek yang terdapat di dalam aplikasi ini. Berdasarkan pada kasus tersebut, fokus utama pada kasus ini adalah penyakit alat reproduksi manusia dan basis pengetahuan yang ditujukan kepada user dan pakar.

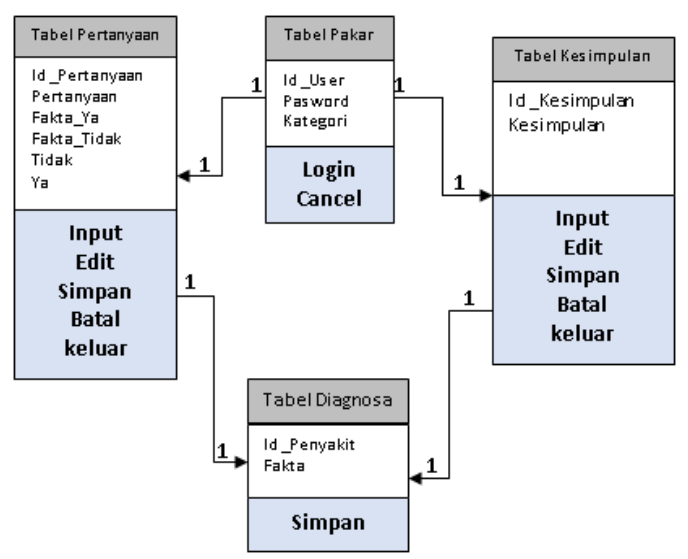

Gambar 7. Class Diagram Aplikasi Penyakit Reproduksi Manusia

\section{HASIL DAN PEMBAHASAN}

\section{A. Struktur Menu Program}

Dalam membangun aplikasi sistem pakar ini dibutuhkan beberapa sub menu yang akan beroperasi di form menu utama untuk lebih jelasnya lihat gambar 8 struktur menu .

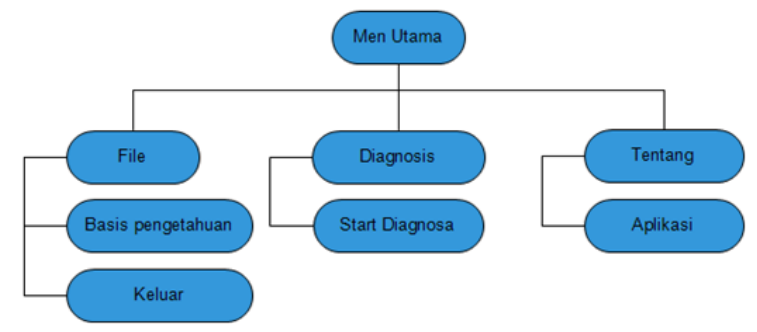

Gambar 8. struktur menu

Gambar 8 Menjelaskan bahwa gambaran aplikasi yang akan menjadi menu-menu dan susb-sub menu utama dimana pakar menjadi controller aplikasi yang mengakses secara penuh tanpa batas, yang di ikuti oleh user yang hanya dapat mengakses beberapa informasi dari aplikasi yang disediakan oleh pakar.

\section{B. Tampilan Menu Utama}

Menu Utama yang meyediakan lima menu utama yang terdiri dari Diagnosis, Basis Pengetahuan berisi Edit pengetahuan, About yang berisi tentang Program dan profil, menu Help yang berisi sekilas penjelasan tentang ilmu-ilmu penyakit alat reproduksi manusia dan menu Close untuk keluar dari program ini 


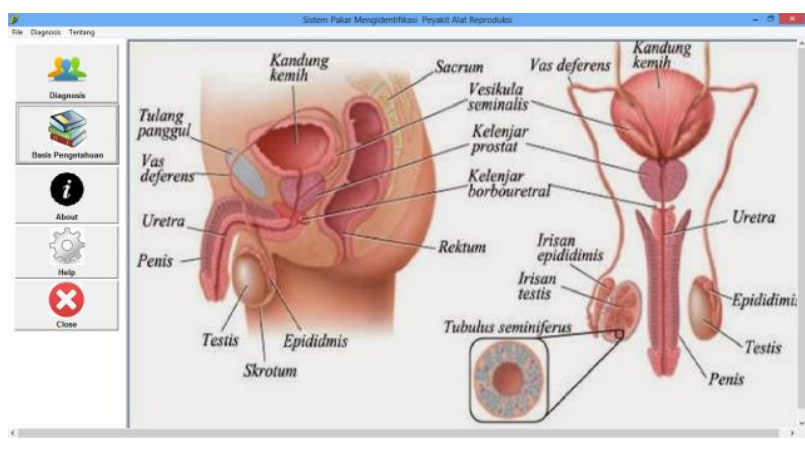

Gambar 9. Menu utama

\section{C. ampilan Form Basis Pengetahuan}

Form Basis Pengetahuan awal dari aplikasi berjalan yang memperlihatkan bahwa tombol simpan, edit hapus non aktif, setelah pakar masuk melalui sub menu edit pengetahuan, kemudian semua edit dan combobox non aktif sebelum pakar mengklik tombol tambah

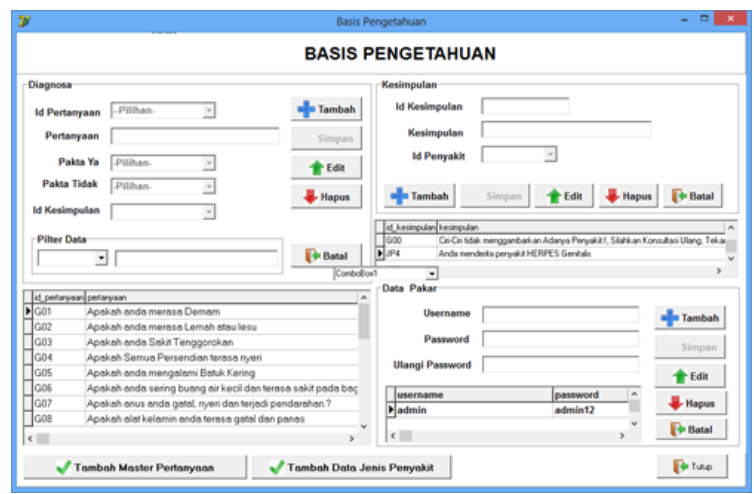

Gambar 10. Basis Pengetahuan

Basis Pengetahuan untuk data master pertanyaan menampilkan untuk penambahan, mengedit, menghapus semua jenis pertayaan yang terdiri dari kode pertayaan dan pertayaan.

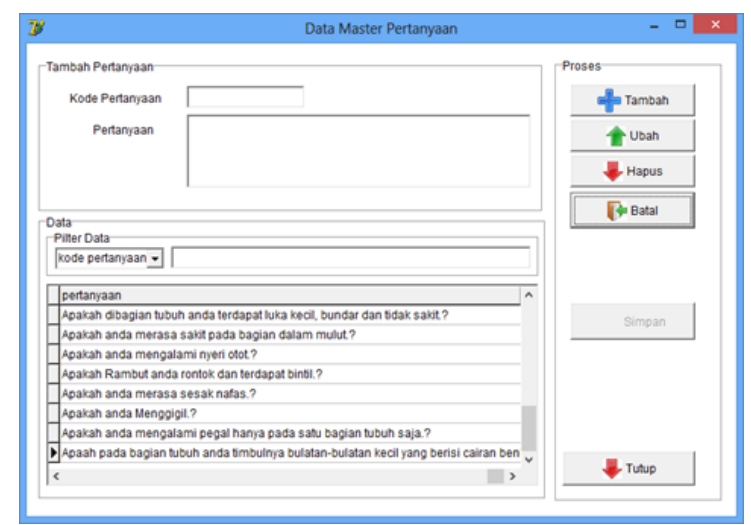

Gambar 11. Basis pengetahuan untuk data master pertanyaan

Basis Pengetahuan untuk Master Data Penyakit Menjelaskan bahwa apabila seorang pakar ingin menambah, menghapus, mengubah data jenis-jenis penyakit alat reproduksi manusia yang terdiri dari Kode
Penyakit, Penyakit dan penjelasan sekilas tentang penyakit tersebut.

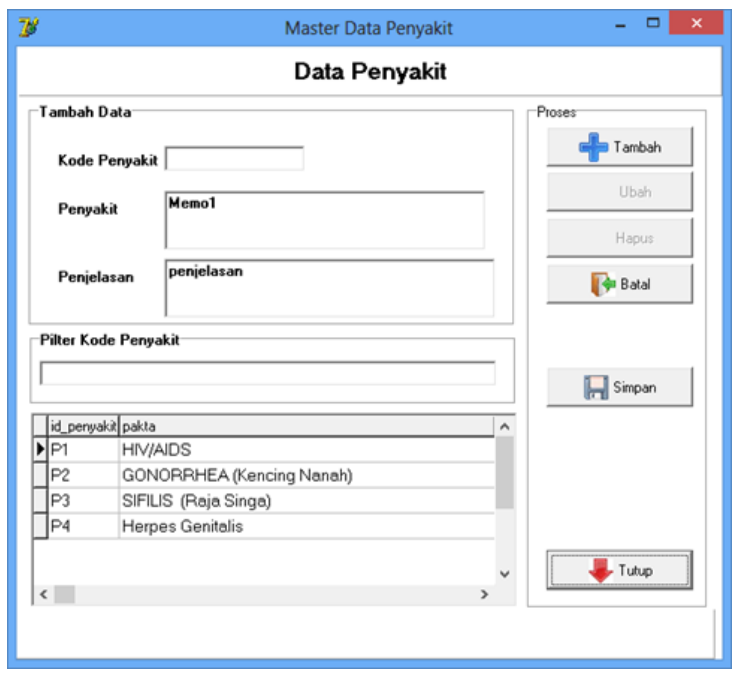

Gambar 12. Tampilan Basis Pengetahuan Data Penyakit

\section{Form Pertanyaan}

Form Pertanyaan menampilkan beberapa informasi yang berupa pertanyaan kepada pengguna untuk segera dijawab yang kemudian akan menghasilkan kesimpulan beserta penjelasan.

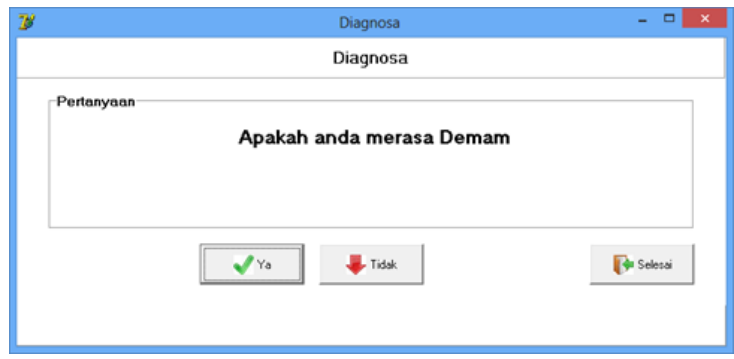

Gambar 13. Form pertanyaan

\section{E. Form Kesimpulan HIV/AIDS dan Penjelasannya}

Merupakan form yang menyediakan informasi hasil deteksi dari pertanyaan yang diinputkan oleh pengguna yang kemudian tersimpan, yang akhirnya akan memberikan hasil kesimpulan sesuai dengan pertanyaan yang di inputkan dan sesuai gejala yang diinformasikan dari pertanyaan yang dijawab oleh Pengguna. 


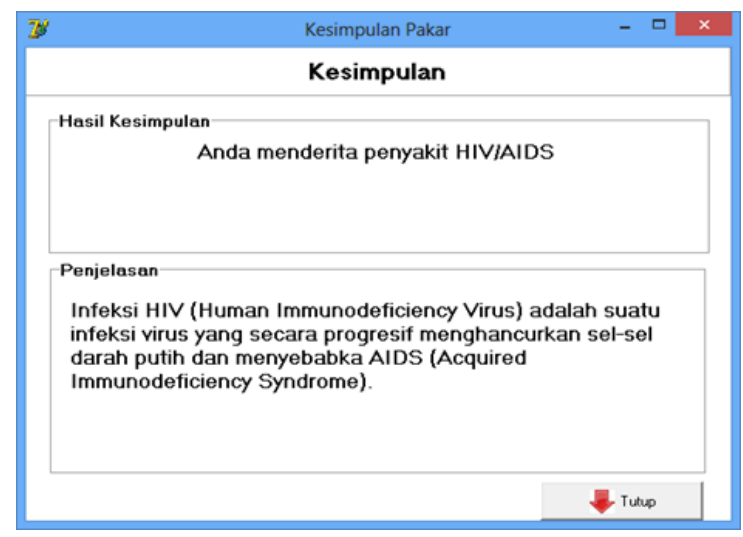

Gambar 14. Form Kesimpulan dan penjelasan

\section{F. Form Help}

Form Help menyediakan tentang informasi yang berupa pengetahuan-pengetahuan yang tentang HIV/AIDS, GONORHEA (Kencing Nanah), SIFILIS (Raja Singa), HERFES (Genitlis) terlihat digambar ada empat tombol untuk setiap jenis macam penyakit alat reproduksi manusia yang memiliki penjelasan yang berbeda.

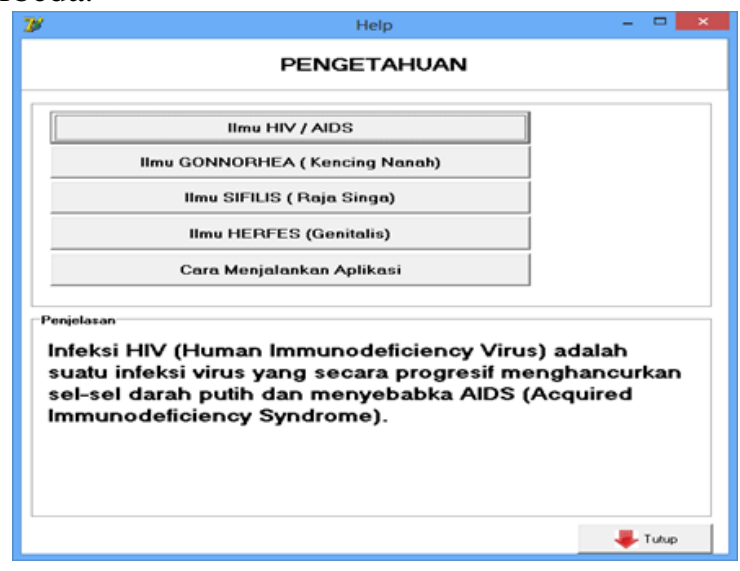

Gambar 15. Form Help

\section{KESIMPULAN}

Dari pembahasan di atas dapat ditarik kesimpulan sebagai berikut :

1. Penerapan metode inferensi yakni metode forward chaining untuk mendeteksi Penyakit Alat Reproduksi Manusia, cocok dengan metode ini, karena diawali dengan gejala-gejala kemudian diakhiri oleh kesimpulan dan penjelasannya.

2. Sistem yang telah dirancang ini dapat memberikan kemudahan bukan hanya untuk penderita penyakit alat reproduksi manusia, akan tetapi semua kalangan yang ingin mempelajari ilmu penyakit alat reproduksi manusia, karena sistem ini menyediakan menu keilmuan yang dapat dipelajari langsung oleh pemakai.

3. Sistem ini dibuat dinamis, sehingga jika suatu saat nanti ada perubahan pengetahuan, maupun penambahan, penghapusan pertanyaan maupun kesimpulan, dapat diubah di menu utama dan pakar dapat mengupdate semua isi data yang ada.
4. Sistem ini terdiri dari empat menu yaitu Menu File, Basis pengetahuan, Pengetahuan, dan Tentang.

\section{DAFTAR PUSTAKA}

[1] Undang-Undang Republik Indonesia Nomor 23 Tahun 1992 Tentang Kesehatan Dengan Rahmat Tuhan Yang Maha Esa Presiden Republik Indonesia http://www.portalhr.com/wpcontent/uploads/data/pdfs/pdf_peraturan/v1204001310.pdf, Mei 2020.

[2] Arhami, Muhammad, 2005, Konsep Dasar Sistem Pakar, Yogyakarta : Andi

[3] Kusumadewi, S. 2003. Artificial Intelligence (Teknik dan Aplikasinya). Yogyakarta: Graha Ilmu.

[4] Kurniasih, S., Aryanto, D. \& Wicaksono, A.P., 2012. Aplikasi Sistem Pakar Untuk Mengidentifikasi Penyakit Pada Hamster (Cricentinae) dan Saran Pengobatannya Menggunakan Metode Backward Chaining.JUITA, II(2).

[5] Kumalasari, I. \& Andhyantoro, I., 2012. Kesehatan Reproduksi Untuk Mahasiswa Kebidanan dan Keperawatan. Jakarta: Salemba Medika. 